\begin{tabular}{|c|c|c|c|}
\hline & Category & Items & $\begin{array}{l}\text { Possible responses } \\
\text { (score) }\end{array}$ \\
\hline$\{1\}$ & $\begin{array}{l}\text { Nutritional } \\
\text { status }\end{array}$ & $\begin{array}{l}\text { Has food intake declined over the past } \\
\text { three months due to loss of appetite, } \\
\text { digestive problems, chewing, or } \\
\text { swallowing difficulties? }\end{array}$ & $\begin{array}{l}\square 0 \text { : severe decrease in } \\
\text { food intake } \\
\square \text { 1: moderate decrease } \\
\text { in food intake } \\
\square 2 \text { : no decrease in } \\
\text { food intake }\end{array}$ \\
\hline$\{2\}$ & & Body-Mass-Index (BMI) $\left[\mathrm{kg} / \mathrm{m}^{2}\right]$ ? & $\begin{array}{l}\square 0: \text { BMI <19 } \\
\square 1: \text { BMI between 19- } \\
21 \\
\square 2: \text { BMI between 21- } \\
23 \\
\square 3: \text { BMI } \geq 23\end{array}$ \\
\hline$\{3\}$ & & $\begin{array}{l}\text { Weight loss during the last three } \\
\text { months? }\end{array}$ & $\begin{array}{l}\square 0 \text { : weight loss }>3 \mathrm{~kg} \\
\square 1 \text { : unknown } \\
\square 2 \text { : weight loss } \\
\text { between } 1 \text { and } 3 \mathrm{~kg} \\
\square 3 \text { : no weight loss }\end{array}$ \\
\hline$\{4\}$ & $\begin{array}{l}\text { Functional } \\
\text { status }\end{array}$ & Mobility? & $\begin{array}{l}\square 0 \text { : bed or chair } \\
\text { bound } \\
\square 1 \text { : able to get out of } \\
\text { bed/chair but does not } \\
\text { go out } \\
\square 2 \text { : goes out }\end{array}$ \\
\hline$\{5\}$ & $\begin{array}{l}\text { Cognitive- } \\
\text { status }\end{array}$ & Neuropsychological problems? & $\begin{array}{l}\square 0 \text { : severe dementia/ } \\
\text { depression } \\
\square 1 \text { : mild dementia/ } \\
\text { depression } \\
\square 2 \text { : no psychological } \\
\text { problems }\end{array}$ \\
\hline$\{6\}$ & Comorbidities & $\begin{array}{l}\text { Takes more than three prescription drugs } \\
\text { per day? }\end{array}$ & $\begin{array}{l}\square 0 \text { : yes } \\
\square 1: \text { no }\end{array}$ \\
\hline$\{7\}$ & & $\begin{array}{l}\text { In comparison with other people of the } \\
\text { same age, how does the patient consider } \\
\text { his/her health status }\end{array}$ & $\begin{array}{l}\square 0 \text { : not as good } \\
\square 0,5 \text { : does not know } \\
\square \text { 1: as good } \\
\square \text { 2: better }\end{array}$ \\
\hline$\{8\}$ & & Age? & $\begin{array}{l}\square 0:>85 \text { years } \\
\square 1: 80-\leq 85 \text { years } \\
\square 2:<80 \text { years }\end{array}$ \\
\hline
\end{tabular}

cohort of elderly patients with OC. Univariate and multivariate Cox regression analyses and Kaplan-Meier method were performed to analyze the impact of the preoperative global health status on survival.

Result(s)* 116 patients entered the study. In multivariate analysis adjusted for clinical-pathological factors, only the G-8 score retained significance as a prognostic parameter of PFS (HR: 2.009; 95\%-CI [1.091-3.699]. 56 patients were classified as G-8 non-frail with an increased PFS compared to 50 G-8 frail patients $(53.4 \%$ vs. $16.7 \% ; \mathrm{p}=0.010)$. A higher CCI was associated with decreased PFS (45.1\% vs. $22.2 \%$; $p=0.012)$ but it did not influence the risk of recurrences or death $(p=0.360$; $\mathrm{p}=0.111$, respectively). The Lee Schonberg prognostic index, the ECOG and mean age were not associated with survival.

Conclusion* The G-8 score independently predicted PFS in elderly OC patients regardless of maximal surgical effort.
Thus, it could be useful to assess surgical treatment based on frailty rather than age alone.

\section{IMPACT OF BRCA \& PD-L1 IN EOC PATIENTS RECEIVING STANDARD 1ST LINE THERAPY +/- PEMBROLIZUMAB: EXPLORATORY ANALYSES FROM THE NEOPEMBROV STUDY (GINECO)}

${ }^{1} \mathrm{O}$ Le Saux, ${ }^{2} \mathrm{AM}$ Savoye, ${ }^{3} \mathrm{MA}$ Mouret-Reynier, ${ }^{4} \mathrm{C}$ Schiffler, ${ }^{5} \mathrm{O}$ Derbel, ${ }^{6} \mathrm{~T}$ Isabelle, ${ }^{7} \mathrm{E}$ Kalbacher, ${ }^{8} \mathrm{~S}$ Gouerant, ${ }^{9} \mathrm{~A}$ Martinez, ${ }^{10} \mathrm{C}$ Cornila, ${ }^{11} \mathrm{M}$ Martinez, ${ }^{12} \mathrm{~L}$ Bengrine Lefevre, ${ }^{13} \mathrm{~F}$ Priou, ${ }^{14} \mathrm{~N}$ Cloarec, ${ }^{15} \mathrm{~L}$ Venat-Bouvet, ${ }^{16} \mathrm{~A}$ Angelergues, ${ }^{17} \mathrm{D}$ Berton, ${ }^{18} \mathrm{O}$ Collard, ${ }^{19}$ E Coquan, ${ }^{20}$ I Ray-Coquard*. ${ }^{1}$ Centre Léon Bérard, Centre de Recherche en Cancérologie de Lyon, Lyon, France; 'Institut Jean Godinot, Reims, France; ${ }^{3}$ Centre Jean Perrin, Department of Medical Oncology, Clermont-Ferrand, France; ${ }^{4}$ Centre Léon Bérard, Direction de la Recherche clinique et de I'Innovation, Lyon, France; ${ }^{5}$ Institut de Cancérologie, Hôpital Privé Jean Mermoz, Lyon, France; ${ }^{6}$ Centre Léon Bérard, Lyon, France; ${ }^{7}$ CHRU Jean Minjoz, Besançon, France; ${ }^{8}$ Centre Henri-Becquerel, Department of Medical Oncology, Rouen France; ${ }^{9}$ Institut Claudius Régaud IUCT-O, Toulouse, France; ${ }^{10}$ Centre Hospitalier Régional d'Orléans, Orléans, France; ${ }^{11}$ Clinique Pasteur, Toulouse, France; ${ }^{12}$ Centre Georges-François Leclerc, Dijon, France; ${ }^{13} \mathrm{CHD}$ Vendée - Hôpital Les Oudairies, La Roche-Sur-Yon, France; ${ }^{14}$ Centre Hospitalier Henri Duffaut, Avignon, France; ${ }^{15}$ Centre Hospitalier Universitaire Dupuytren, Limoges, France; ${ }^{16}$ Groupe Hospitalier Diaconesses Croix Saint-Simon, Department of Medical Oncology, Paris, France; ${ }^{17}$ ICO - Centre René Gauducheau, SaintHerblain, France; ${ }^{18}$ Institut de Cancérologie de la Loire - Lucien Neuwirth, Department of Medical Oncology, Saint-Priest-en-Jarez, France; ${ }^{19}$ Centre François Baclesse, Department of Medical Oncology, Caen, France

\subsection{6/ijgc-2021-ESG0.369}

Introduction/Background* In the randomized phase II NeoPembrOV study (NCT03275506), Pembrolizumab in combination with neoadjuvant chemotherapy (NACT) met its primary endpoint of complete debulking rate (CRR) for the treatment of patients with advanced up-front non-resectable high-grade serous ovarian cancer (HGSOC). However, the CRR in the control group was similar. Identification of potential predictive biomarkers is fundamental to better understand the place of Pembrolizumab in this setting.

Methodology 91 Patients (pts) with HGSOC unable to received complete upfront debulking surgery were included and received Carboplatin (AUC5) Q3W + Paclitaxel $(175 \mathrm{mg}$ / $\mathrm{m}^{2}$ ) Q3W +/- Pembrolizumab $200 \mathrm{mg}$ Q3W IV before and after surgery. Pembrolizumab was given until 24 months maximum. After interval debulking surgery, optional bevacizumab was proposed. BRCA1/2 mutation status (BRCA) was assessed using standard algorithms. Immunohistochemical PD-L1 expression was evaluated on both tumour and immune cells (IC) using the Ventana SP263 assay. Associations of progression-free survival (PFS) with BRCA, and PD-L1 expression were evaluated.

Result(s)* BRCA status was available for 81 pts (89\%). 3 out of 30 pts $(10 \%)$ in the control arm harboured a BRCA mutation (mBRCA) versus $13 / 61$ in the experimental arm (21.3\%). Median PFS (mPFS) in both arms in the BRCA wild-type (wtBRCA) subgroup were not different (mPFS 20.8 months [95\% IC,15.0-25.7] vs 18.2 months [95\%IC, 16.8.0-21.4] in control and experimental arms respectively). mPFS in the $\mathrm{mBRCA}$ subgroup were not reached in both arms. PD-L1 expression was available for $85 / 91$ patients (93.4\%). PD-L1 IC $\geq 5 \%$ was positive in $29 / 85$ patients $(34.1 \%)$ and correlated to mPFS in the whole population $(18.2 \mathrm{~m}$ in PDL1 IC $<5 \%$ vs $23.4 \mathrm{~m}$ PD-L1 IC $\geq 5 \%$ respectively, $p=0.02)$. mPFS was 
similar HR: 1.39 [0.71-2.74] in patients with PD-L1 IC $<5 \%$ (mPFS 19.3mo [14.9-25.7] vs mPFS $18.2 \mathrm{mo}$ [14.5-19.3] in control and experimental arms respectively). Pembrolizumab improved mPFS (HR: 0.56 [0.19-1.61]) for pts with PD$\mathrm{L} 1 \geq 5 \%$ (mPFS 20.8 mo [9.5-NE] vs mPFS $23.4 \mathrm{mo}$ [18.0-NE] in control and experimental arms respectively).

Conclusion* If no benefit in adding Pembrolizumab to CT +/bevacizumab was found in wtBRCA subgroup, exploratory PFS analyses in the PD-L1 IC $\geq 5 \%$ subgroup showed a trend favouring Pembrolizumab in patients with advanced HGSOC.

\section{PROGNOSTIC IMAGE-BASED QUANTIFICATION OF CD8CD103 T CELL SUBSETS IN HIGH-GRADE SEROUS OVARIAN CANCER PATIENTS}

\begin{abstract}
${ }^{1,6}$ ST Paijens, ${ }^{1,6} \mathrm{~A}$ Vledder* ${ }^{*}, 6 \mathrm{D}$ Loiero, ${ }^{3} \mathrm{EW}$ Duiker, ${ }^{3} \mathrm{~J}$ Bart, ${ }^{4} \mathrm{AM}$ Hendriks, ${ }^{4} \mathrm{M}$ Jalving, ${ }^{1} \mathrm{HH}$ Workel, ${ }^{3} \mathrm{H}$ Hollema, ${ }^{3} \mathrm{~N}$ Werner, A Plat ${ }^{1},{ }^{1} \mathrm{GBA}$ Wisman, ${ }^{1} \mathrm{R}$ Yigit, ${ }^{1} \mathrm{H}$ Arts, ${ }^{5} \mathrm{AJ}$ Kruse, ${ }^{5} \mathrm{NM}$ de Lange, ${ }^{2,7} \mathrm{VH}$ Koelzer, ${ }^{1,7} \mathrm{M}$ de Bruyn, ${ }^{1,7} \mathrm{HW}$ Nijman. ${ }^{1}$ University of Groningen, University Medical Center Groningen, Department of Obstetrics and Gynecology, The Netherlands; ${ }^{2}$ Department of Pathology and Molecular Pathology, University Hospital and University of Zurich, Switzerland; ${ }^{3}$ University of Groningen, University Medical Center Groningen, Department of Pathology, The Netherlands; ${ }^{4}$ University of Groningen, University Medical Center Groningen, Department of Medical Oncology, The Netherlands; ${ }^{5}$ /sala Hospital Zwolle, Department of Obstetrics and Gynecology, The Netherlands; ${ }^{6}$ Contributed equally; ${ }^{7}$ Shared senior authorship
\end{abstract}

10.1136/ijgc-2021-ESGO.370

Introduction/Background* CD103-positive tissue resident memory-like CD8 + T cells (CD8CD103 TRM) are associated with improved prognosis across malignancies, including highgrade serous ovarian cancer (HGSOC). We investigated whether quantification of CD8, CD103 or both is required to improve existing survival prediction and whether all HGSOC patients or only specific subgroups of patients benefit from infiltration.

Methodology We applied image-based quantification of CD8 and CD103 multiplex immunohistochemistry in the intratumoral and stromal compartments of 268 advanced-stage HGSOC patients from two independent clinical institutions.

Result(s)* Infiltration denisty of CD8CD103 TRM was independent of clinicopathological factors and primary treatment strategy. A survival benefit of CD8CD103 TRM infiltration was observed in patients treated with primary cytoreductive surgery. Moreover, survival benefit in this group was limited to patients with no macroscopic tumor lesions after surgery (high epithelial CD8CD103 TRM infiltration 5 year survival $83 \%$ versus $52 \%, \mathrm{p}=0.03$; high stromal CD8CD103 TRM 5 year survival $77 \%$ versus $54 \%, p=0.01)$. No effect of CD8CD103 TRM infiltration on overall survival was observed in patients treated with neo-adjuvant chemotherapy, with or without macroscopic tumor lesions after surgery (high epithelial CD8CD103 TRM infiltration, $p=0.77$; high stromal CD8CD103 TRM infiltration, $p=0.32$ ).

Conclusion* Our results suggest CD8CD103 TRM quantification as a superior method for prognostication compared to single CD8 or CD103 quantification, and supports the further exploration of image-based quantification of CD8CD103 TRM in HGSOC. This approach provides novel insights into

a. High CD8CD103 TRM stromal and epithelial infiltration, HGSOC tissue

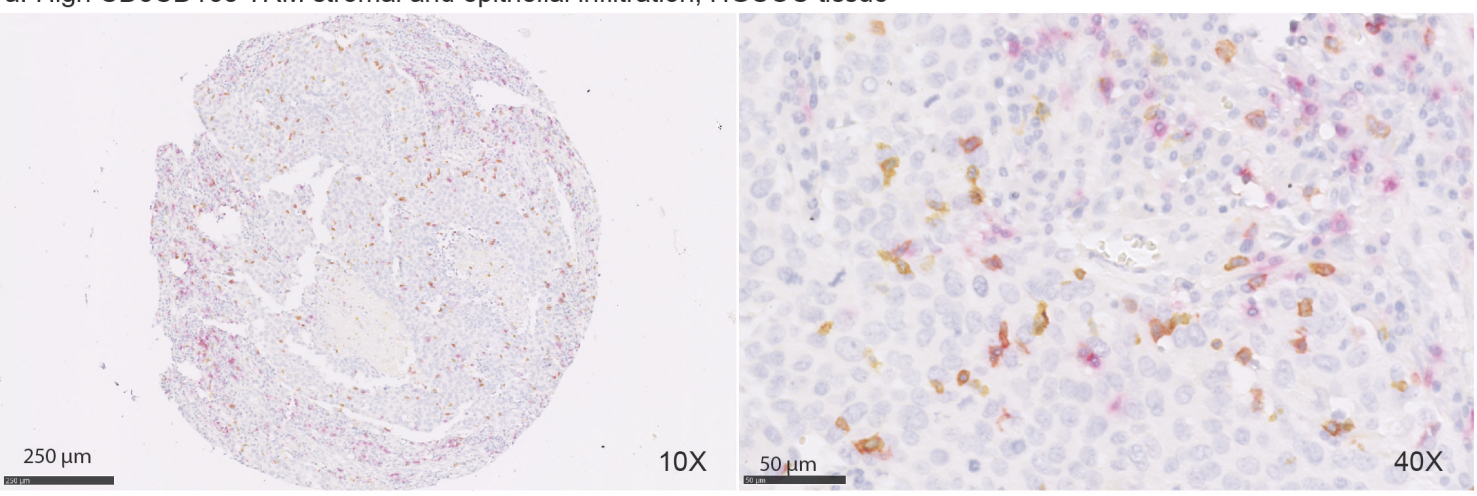

b. Low CD8CD103 TRM stromal and epithelial infiltration, HGSOC tissue

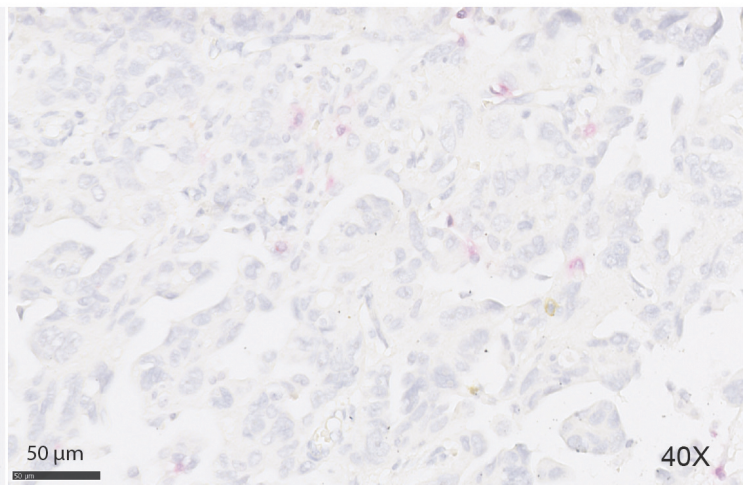

Abstract 263 Figure 1 Examples of representation CD8CD103 double staining assessed by immunohistochemistry 